operate mainly on old culm banks, and an increase of 16 per cent. in the quantity of coal dredged from rivers.

The production in the Lehigh region was $10,929,055$ gross tons; in the Schuylkill region, $23,659,448$ tons; in the Wyoming region, 42,111,732 tons; and in Sullivan County (Bernice Basin), 494,848 tons.

There was a large decrease in the number of men employed in the production of anthracite in 1916, and the output was maintained only through an increase in the number of working days. The number of men employed in 1914 was 179,679 ; in 1915, 176,552; and in $1916,159,869$. The average number of days worked was 245 in 1914, 230 in 1915, and 253 in 1916. The average output per man per day in 1914 was 1.84 gross tons; in $1915,1.96$ tons, and in 1916, 1.93 tons. The average output per employee for the year was 451 tons in 1914; 450 tons in 1915; and 489 tons in 1916.

\section{ANIMAL COLLECTIONS FROM AUSTRALIA}

THe animal collections of the Zoological Park have been enriched by the arrival of another great "caravan" from Australia. After six months of diligent effort, and generous expenditures of money, Mr. Ellis S. Joseph brought together and successfully transported to New York the largest collection of rare species of mammals, birds and reptiles that ever came to America. The common species, such as for years have been coming to us through the regular European channels, are conspicuous by their well-nigh complete absence.

Naturally, the officers of the Zoological Society feel measurably elated over this coup, at a period of great depression in the wild-animal supply from other sources. The receipts from England are very trifling, and from the continent of Europe nothing whatever comes. In fact, in America the German wild-animal business is thoroughly dead. Our further operations in South Africa must be postponed until after the war.

Encouraged through his previous reception by the Zoological Society, Mr. Joseph re- doubled his former efforts to bring to America something worth while. The collection which he landed in Victoria, B. C., a month ago represents a large outlay in money and effort, and great scientific value. Of that importation the Zoological Society has purchased mammals, birds and reptiles to a total cost of about $\$ 6,000$. The Philadelphia Zoological Society has purchased $\$ 3,000$ worth, and other purchases are proceeding.

The following list shows the newly acquired mammals :

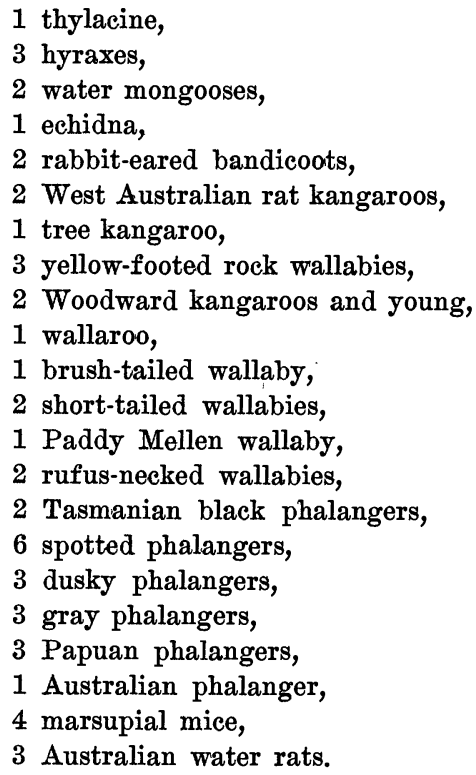

The majority of our accessions will be found in the large bird house, the small deer house, the reptile house and the small mammal house, but the thylacine is in one of the small bear dens. Each new species is marked by a red label reading "Recent Accession." Incidentally it is to be noted that our total kangaroo collection is believed by Mr. Joseph to be the most extensive series ever brought together. It will be found in the small deer house. W. T. Hornaday, Director

\section{SCIENTIFIC NOTES AND NEWS}

Professor Milo S. Ketchum, dean of the College of Engineering of the University of Colorado, was elected president of the Society 